\title{
Constructing EU Identity through LGBT Equality Promotion: Crises and Shifting Othering Processes in the EU Enlargement
}

\author{
Koen Slootmaeckers - City, University of London
}

The EU sees itself as a beacon of LGBT-friendliness and seeks to promote these norms in its external relations. However, such identity claims and norm promotion are inherently political and should be critically examined as such. Taking a relational approach, this article conceptualises and examines the Othering processes within the EU enlargement to highlight the political nature of what is often described as a technocratic. Through exploring the triangulation of the EU enlargement, Othering processes, and crises, it is argued that 1) the use of LGBT rights as a measure of Europeanness is based on a longer tradition of defining the EU's symbolic boundaries, but that 2) it is in perceived moments of crisis that the EU redraws and strengthens the boundaries between the Self and the different type of Others through changing combinations of Othering mechanisms. Finally, the article also argues that LGBT rights promotion is not only a tool in constructing the EU's identity but also a source of an identity crisis, as is shown by the rise of anti-gender politics.

Keywords: EU Identity, homonationalism, Othering, LGBT Politics, Crisis

\section{Introduction}

The European Union ( $\mathrm{EU}^{1}$ ) defines itself as a 'community of values' and as a beacon of lesbian, gay, bisexual and transgender (LGBT) friendliness in the world; in the 2010s, the protection of LGBT rights has developed into a litmus test for candidate countries' Europeanness (Slootmaeckers, 2017a). Such identity claims, however, should be critically examined as they are the result of an underlying politics of inclusion and exclusion. In this article, I analyse how the EU's self-presentation of LGBTfriendliness emerged as part of a wider agenda of (re)defining its symbolic boundaries. In particular, I am interested in the underlying processes of Othering embedded in the EU's pro-LGBT external policy and how these emerged as a response to crises of identity.

\footnotetext{
${ }^{1}$ I use European Union to refer both to the current structure of the EU and its old, pre-Maastricht Treaty (1993) structure of the European Communities.
} 
Although Manners' (2002) notion of "normative power Europe" can and should be problematised, the ensuing literature provides a useful entry point into these questions. Not only does it draw attention to how EU identity is constructed through its relationality with the rest of the world (the Other), but also to the fact that the EU's external relations are "crucially determined by the nature of [its] international identity" (Manners and Whitman, 2003). Engaging this literature within broader debates in International Relations (IR) scholarship, I take EU enlargement as a case study. EU enlargement is the process par excellence to investigate the boundary work embedded within the EU's political project and how crises have contributed to such processes. EU Enlargement as a process does not only define and redefine the EU's physical borders, but also its symbolic boundaries (Kuus, 2007). Additionally, it is ever-evolving, with existing rules and strategies for expansion continually redefined, whilst new ones are crystallised (Kochenov, 2008). As such, EU enlargement provides the perfect site to investigate continuity and change in how the EU defines itself through its relations with its Others, and what role is played by moments of crisis.

Whereas a majority of the literature on EU enlargement and LGBT rights has studied the domestic impact of the EU on LGBT rights in new member states (e.g. Ayoub, 2016) or with LGBT politics in Eastern Europe and the Balkans (e.g. Kuhar and Takács, 2007), this article focusses on the boundary work LGBT rights are doing within the enlargement process. Such analysis is guided and inspired by previous work on the link between Europe and LGBT rights (e.g. Ayoub and Paternotte, 2014), on Europe's symbolic boundaries and identity (e.g. El-Tayeb, 2011), as well as by the literature drawing on Puar's (2007) conceptualization of homonationalism and how LGBT rights have developed in a marker of modernity (see also Rahman, 2014). Examining the triangulation of EU enlargement, Othering, and crisis, I argue that the EU symbolic boundaries between the Self and its different Others are consolidated, reconsidered and transformed in response to identity crises. I demonstrate that the emergence of LGBT rights as an identity marker is both a continuation of a longer tradition of defining the EU's symbolic boundaries as well as a transformation of this tradition. I further highlight that the evolution of EU enlargement is not a linear progression toward normative 
othering, but instead, that the EU's boundary making is based on a pseudo-hierarchy of different Self/Other relations and Othering processes that shift in respond to different crises.

The contribution of the article is threefold. First, the article contributes to the emerging literature that examines the notion of the EU's LGBT-friendliness. My analysis demonstrates how continuities and changes in the enlargement process have contributed to the current LGBT-friendly identity. Second, the article speaks to the Europeanization literature and its conceptualisation of enlargement. By investigating the Othering processes that are embedded within EU enlargement, I highlight the political nature of a set of practices and policies related to accession that are often described as merely technocratic. Finally, the article contributes to wider theoretical debates on (international) identity formation by highlighting how crises contribute to the activation, deactivation and reactivation of the different Othering processes that underpin the construction of the Self.

The article is part of a wider research agenda on the promotion of and resistance to LGBT rights within the EU enlargement process (see Slootmaeckers, 2017a). The theoretical argument draws from existing literature as well as the findings of the presented case study and the wider research project. The empirical part is based on a process-tracing analysis of the evolution of LGBT rights within EU enlargement. As part of the larger project, I conducted 112 interviews between 2012 and 2016 with a variety of actors, including LGBT activists in Europe, Members of the European Parliament, and European Commission officials. These data are triangulated with and complemented by a document analysis of most notably the EU progress reports. Based on a relational ontology (Qin, 2018), the analysis takes as its primary object the Self/other relations and Othering processes that underpin the EU enlargement, rather than actors and their specific actions. This is not to say, however, that actors do not play a role in these processes, but rather that the analysis of how actors enact the identified processes is beyond the scope of this article.

The article proceeds as follows. First, it theorises the EU's Self/Other relations and underpinning Othering processes. The following two sections trace the changes to the Enlargement process 
following two crises. The first takes the identity crisis that emerged following the fall of the Berlin Wall as it starting point, whilst the next section considers the internal challenges to the EU's fundamental rights identity following the 2004 enlargement and traces how the EU has responded by emphasising LGBT rights in relation to its Others. The final section discusses some important nuances by examining the relationality of different Othering processes within enlargement as well as how they are themselves both a response to and a source of crisis.

\section{Theorising EU's Self/Other Relations and Othering Processes}

This article focusses on the processes through which EU identity is constructed and maintained, taking into account that these relations and processes are ever-evolving. From such a perspective, EU identity ${ }^{2}$ is conceptualised as the product of a system of self/other relationships that themselves are each governed by different Othering processes. What identity becomes foregrounded, then, is determined by which Self/Other relations are highlighted and which othering processes are activated. This section will expand on this theoretical view as follows. First, it briefly discusses Othering as a means of international identity production. Next, the emphasis on processes is applied to the Normative Power Europe literature's typology of the EU's others (Diez, 2005). Doing so, the section highlights not only what different othering processes govern the typology, but also draws attention to the type of borders that are constructing. Finally, the section focusses on the dynamic nature of the EU's identity. As the EU's identity is the result of a system of relations, the concept of crisis is invoked to theorise how change in the system of Othering occurs.

Othering can be understood as a theory on the Self and the Other, in which the former is constructed through its juxtaposition to the latter (Jensen, 2011). It captures the process of "differentiation and demarcation by which the line is drawn between 'us' and 'them' [...] and

\footnotetext{
${ }^{2}$ Although identity is used here in its singular form, the reader should remain mindful of the fact that the EU identity is always one of many which are each produced through different self/other relations and othering processes.
} 
through which social distance is established and maintained" (Lister, 2004: 101). Although presented as distinct, the 'Self' and the 'Other' are inherently related and interdependent. The Othering process does not simply valorise the Self whilst vilifying the Other, but involves "a double movement, where the Other is simultaneously emulated and repudiated, admired and despised, and the source of this ambivalence is the recognition of Self in Other" (Sax, 1998: 294). Hence, the Self's identity does not exist by itself, but is situated within and constructed through the specific relationship between the Self and its Others (Harrison, 2003). This being the case, the Self (and ensuing identity) is never a singular, nor an essential category, but always contextual and relational. The Self is thus always multifaceted (Neumann, 1998); depending on which aspects of the Self/Other relationship are foregrounded in the Othering processes, different identities will emerge.

Hence, as it is situated within a variety of Self/Other relations, the EU's identity should also be considered as multiple, fluid and constantly (re-)constructed through transactions with different Others (Rumelili, 2004). The normative power Europe literature has provided a typology of four different Other positions against which the EU defines itself (Diez, 2005): The (past) Self as Other, the Other as 'Existential Threat', as 'Inferior', and as 'Violating Universal Norms'. In addition to these, two Self positions can be distinguished: the EU as protector of fundamental rights and as peace project (Slootmaeckers, 2017a).

Although these Self and Other positions are useful tools for the analysis presented in this article, they tend to obscure the processes that contribute to their relative positioning. Indeed, considering the relationality of identities and the fact that their perceived "stability is an ongoing accomplishment of practices that represent self and other in certain ways" (Wendt, 1994: 386), I argue that these different self/other positions are dependent on different and fluid Othering processes. Thus, taking a more relational approach, one can re-analyse Diez's (2005) typology to distil three types of othering processes that in different combinations and imbrications govern these self/other relationships. These are geopolitical, normative, and/or temporal Othering processes. Whereas geopolitical Othering relies on security issues and realpolitik to define the symbolic 
boundaries of the EU, normative processes function through highlighting differences in norms. Temporal Othering, on the other hand, creates and maintains boundaries by positioning the Self and the Other in different temporalities, often with the Other lagging behind the Self or by the abjection of past versions of the self. It is through different combinations and imbrications of these processes that different self/other relations are produced and maintained (see figure 1 for a more detailed overview of this analysis).

Figure 1: The EU's Self/Other relations and the governing Othering mechanisms

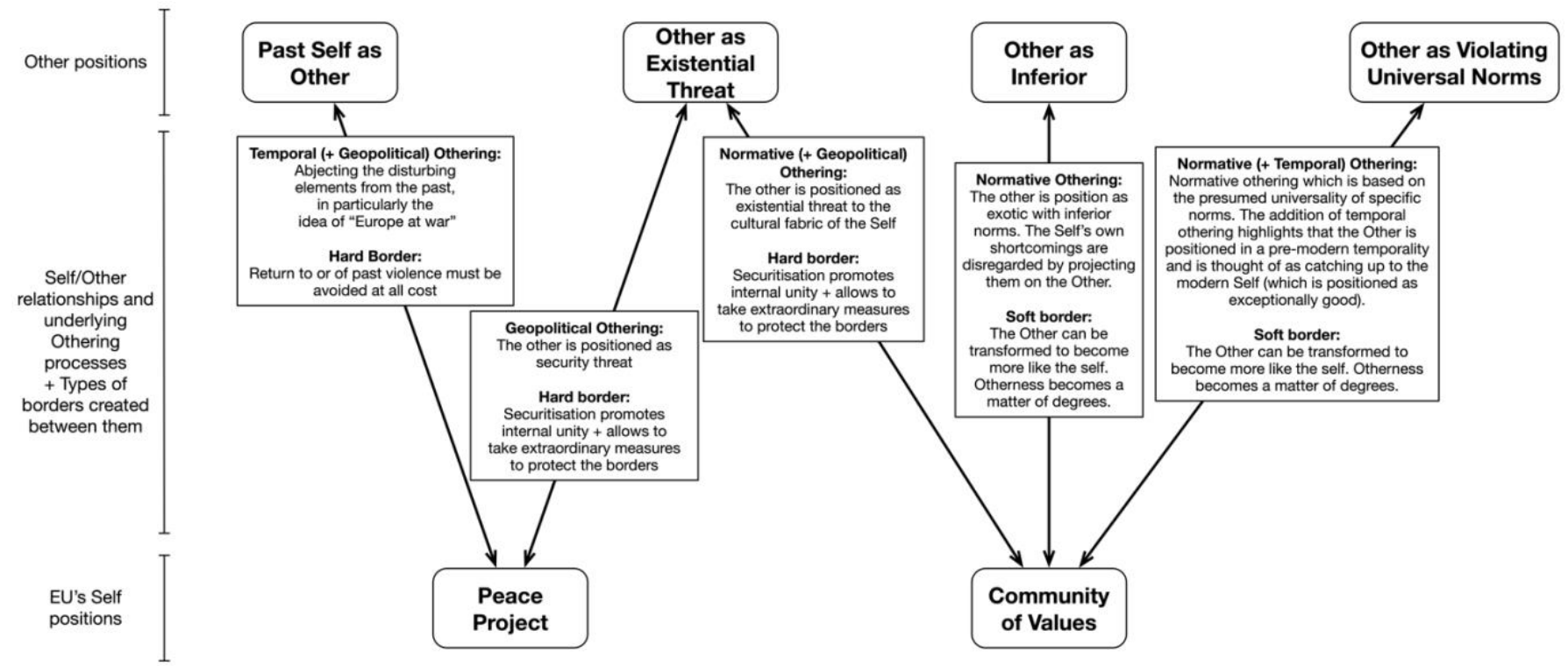

Foregrounding processes does not only allow to focus on the different types of Othering that govern the self/other relations, but also draws attention to the types of boundaries that are created. Indeed not all boundaries between the Self and Other are hard borders (Delanty, 2006). The penetrability of these boundaries depends on the type of Othering processes that are employed (Rumelili, 2004). Geopolitical processes tend to lead to hard borders as they position the Other as a threat to the self that cannot be allowed to transgress the border. Normative Othering, on the other hand, tend toward less clear-cut boundaries because the norms that underpin such processes othering are inherently contested. Thus, rather than producing hard borders, normative othering processes produce blurred boundaries, which are 1) permeable as Otherness exists in degrees and can be shed 
(Kuus, 2007), and 2) in part dependent on the Other's behaviours towards the Self (Rumelili, 2004). When the Other accepts its position vis-à-vis the Self, little effort is required to establish, maintain, and/or emphasise (symbolic) boundaries. However, if the Other resists the Self's identity, the Self's identity is undermined, the process "therefore creates a greater necessity to reinscribe the identity of the self and the differences of the other" (Rumelili, 2004: 37-38), and thus to intensify the Othering processes.

A final point to consider is the dynamic nature of these Self/Other relationships and the fact that Othering processes can shift over time (Neumann, 1998). As already alluded to above, when the self's identity is being resisted, different othering processes might be activated. To provide a more theoretical account of continuities and change of othering process, the concept of crisis provides useful insights. A crisis represents a moment of "disorder in the seemingly normal development of a system", and is transitional phase "in which the normal way of operating no longer works" (Boin et al., 2005). Crisis then is often experienced as the questioning or undermining of the basic structure of the system that requires a response, i.e. change is needed to deal with the caused instabilities and insecurities (Boin et al., 2005). From this perspective, I argue that when the EU faces a crisis in its self/other identity system (henceforth also identity crisis), there is a need to reconsider how the EU defines, produces, and/or reinforces its identity through different Othering processes and different types of Others.

The ways in which crisis can impact underlying Othering processes are multiple, and in part dependent on the roots of this identity crisis. Nonetheless, two main causes of identity crisis can be observed. First, a crisis can occur as consequence of external events that cause a fundamental shift in the identity system (e.g. the end of the Cold War, the financial crash). The external disruption can lead to the questioning and/or repositioning of the Self/Other relationships. This, in turn, might lead to changes in Othering processes to cope with the new environment. Second, the source of crisis can be internal to the identity system. As mentioned before, a transgression of hard identity boundaries can create a crisis by disrupting the imagined internal unity. Such an event would require 
extraordinary measures to secure the boundaries of the Self. Alternatively, an identity crisis can emerge when the Other does not recognise the Self's identity or its own relational positioning. Such resistance puts the identity system under stress and requires action. Dealing with such crises would require either strengthening existing Othering processes to reinforce extant Self/Other differences or shifting focus to different Self/Other relationships and emphasising other differences (Rumelili, 2004). The successfulness of these strategies remains, however, dependent on the extent to which they can re-stabilise the Self/Other relationships and reduce resistance.

In short, I argue that when a crisis is experienced and the normal Othering processes are no longer adequate or sufficient to (re)define the EU's identity, a shift in the relative saliency of the different Othering processes will occur. I demonstrate this argument through the examination of how the Othering processes that underpin the EU enlargement process have shifted in response to different crises. I do so first, by starting from the end of the Cold War as an external source of an identity crisis and tracing how the EU responded to it in terms of shifting Othering processes. The next section starts from increased contestation over EU norms following the 2004 enlargement as an internal source of identity crises and traces how this contributed to the emergence of increased reliance on LGBT-friendliness as means of othering.

\section{After the Fall of the Berlin Wall: The EU's Emerging Normative Othering Processes}

The end of the Cold War has been described as a "tremor that is shaking what are called Central and Eastern Europe" (CEE), and which is "no doubt the immediate cause of [...] this debate on the 'European cultural identity'” (Derrida, 1992: 19). As an external event, it fundamentally altered the EU's environment and required the EU's (symbolic) borders to be redefined. To illustrate, apart from the more general geopolitical East-West division that structured the Cold War period, the EU's Other in this time was defined merely as its "own past which should not be allowed to become its future" (Wæver, 1996: 122). Indeed, for as long as the continent was divided by the Iron Curtain, the European integration project took place in a "definitional vacuum", i.e. it was possible to talk of the 
EU and Europe without ever "having to confront the question of what Europe meant" (Crouch and Marquand, 1992: 1). However, with the collapse of the Soviet Union, the political nature of Europe could no longer be taken for granted (Wallace, 1992). This new geopolitical situation presented the EU with a double challenge to both 'reunify' Europe to avoid security threats and define its final borders (Smith, 2005). To do so, the processes underpinning EU identity began to gradually move away from the temporal and geopolitical othering to include normative processes (Diez, 2004). Doing so, the EU began to define itself as founded on the principles of democracy, later to be extended to include the respect for human rights and fundamental freedoms (Smismans, 2010).

The changes made to EU Enlargement rules and practices were a key part in this process. In response to the emerging and elusive question of what defines 'Europe', the 1993 Copenhagen European Council summit adopted the Copenhagen criteria for accession, demanding that candidate countries must have stable institutions guaranteeing democracy, rule of law and human rights (Kochenov, 2008). The Amsterdam Treaty (1999) solidified this move by amending the Treaties to explicitly state the normative foundations of Europe as well as by codifying the Copenhagen criteria as membership conditions (Kochenov, 2008). With an eye on the later development of the EU's LGBT-friendly identity, it is important to note that the Amsterdam Treaty also extended the legislative (human rights) competences of the EU to include, amongst others, LGBT rights (albeit as an add-on, see Mos, 2014). By doing so, the first steps were taken on the path to formally include LGBT rights in the EU human rights identity. Still, the prominent role of LGBT rights within the EU's Othering processes would not emerge until after the 2004 Enlargement (see infra).

The adoption of the Copenhagen criteria signalled a shift in how the EU defines its Others: from temporal Othering to more normative Othering processes (Diez et al., 2006). Indeed, Kuus (2007) convincingly argued that the enlargement rhetoric called into existence the idea of 'Eastness', which exists in contradiction to the 'Europeanness' of the EU's so-called founding values (Kovács and Kabachnik, 2001). Nevertheless, whilst normative Othering processes made their entrance in the enlargement discourse, geopolitical and temporal Othering remained key. Consider, for example, 
how the enlargement remained discursively framed through the notion that Eastern Europe represented a potential reincarnation of the 'past Self'. Overcoming conflicts and maintaining peace and stability was the main "legitimization for the [EU] enlargement towards Central and Eastern Europe " (Diez et al., 2006: 563). Indeed, the Eastern enlargement was put on the agenda in the early 1990s by arguing that a clear EU membership perspective for CEE countries would be the only way to guarantee stability in the region (Higashino, 2004).

Similarly, the application of the Copenhagen criteria to Eastern enlargement further illuminates a tension between geopolitical and normative Othering processes. Whereas the decision on which countries would be included in this round of accession was initially based on the fulfilment of the Copenhagen criteria, this logic was sidelined in response to the Kosovo war (1998-1999). The conflict was seen as an 'existential threat' that could only be contained by creating a hard border between the security threat and the countries in CEE (geopolitical Othering), thus pushing the enlargement process forward, even if that meant not upholding a hard line on the Copenhagen criteria (Higashino, 2004).

In sum, although normative Othering processes emerged as a response to the identity crisis that followed the end of the Cold War, this shift remained gradual and incomplete. In fact, as the Copenhagen criteria (the basis of normative othering) were considered as an instrument to ensure stability and security in Europe (Smith, 2001), the main Othering processes within the EU enlargement remained geopolitical and temporal, with CEE as the (potential) contemporary incarnation of the past Self.

\section{Identity Resistance and the foregrounding of LGBT rights}

Intended to reunite the European continent, the 2004 Enlargement also created an inherent tension within the EU identity system. By drastically changing its borders, the EU now includes countries previously considered its (inferior) Other. Although within normative Othering processes, Other-toSelf transitions are theoretically possible, the enlargement process did not lead to such 
transformation. Indeed, the secondary nature of the Copenhagen criteria within the enlargement process resulted in limited transformations of the new member states (Kochenov, 2008), which left room for internal contestation of EU's human rights identity (see Fuchs and Klingemann, 2002). Thus, while the Copenhagen criteria allowed for the construction of the EU's human rights identity, the practice of enlargement itself increased cultural and political plurality within the EU, which in turn could lead to challenges and resistance to the EU's identity based on these normative elements. Developments in some of the new member states demonstrate that internal resistance to aspects of the EU's human rights identity emerged relatively quickly after accession. Such resistance became particularly visible with regards to LGBT issues, which, after the enlargement, became a contentious topic of social and public debates in some new member states (O'Dwyer, 2010). While they had to adopt some LGBT equality legislation as part of the accession process, some countries saw politicians then instrumentalise homophobic (nationalist) language to gain political capital after accession. Examples of such processes have been observed in Hungary (Renkin, 2009), Latvia (Putnina, 2007), Lithuania (Davydova, 2012), Poland (Graff, 2006), as well as in soon to be member state Romania (Carstocea, 2006). Within such discourses, the EU's push for LGBT equality was often presented as a threat to the nation and local culture (Renkin, 2009). In Latvia, for example, the discourse emerged that the EU's insistence on LGBT rights constituted a direct attack by the so-called 'international gay lobby' on the future of the nation (Mole, 2011). Similarly, in Poland, the 2006 Kaczyński government declared that it would prevent the EU's "aggressive promotion of homosexuality", noting that "although Poland may have joined the EU, they [Polish people] will have none of the EU's 'loose' attitudes toward sex" (Graff, 2006: 436). Such contestation of the EU's values-based identity did not remain discursive, as some countries banned gay prides (e.g. Poland) and/or introduced homophobic laws (e.g. Lithuania) (Slootmaeckers and Touquet, 2016).

Although the uniquely "eastern" location of these developments should be questioned (Kulpa, 2014), they represent a resistance to the produced EU identity, which necessitates a response. As theorised, the identity crisis requires actions to solidify and enforce the EU's symbolic boundaries. 
Regarding the resistance to LGBT equality as a shared European value, two changes in Othering processes can be observed. As demonstrated in the next section, both changes respond to the identity resistance by making LGBT issues more salient in the EU's Othering processes. These changes should be considered against the background of a more general and global process in which LGBT rights became part of the universal human rights architecture (Kollman and Waites, 2009) and in which LGBT rights became a marker of what it means to be modern (Puar, 2007).

\section{The EU's LGBT-friendly identity as Response to Identity Resistance}

In order to cope with the crisis caused by the resistance of some new member states to some of the EU's identity markers, action was required to reinforce the EU's symbolic boundaries. Two changes in othering process are of particular interest: the redrawing of the EU's symbolic boundaries by expelling internal elements of Otherness, and the intensifying of Othering processes between the Self and the external Other based on the challenged elements of the EU identity.

To illustrate the former change in Othering processes, consider the resolutions passed by the European Parliament in response to the increased levels of homophobic politics in the new member states. Whilst these resolutions denounced homophobia in Europe as a whole, they singled out CEE as the EU's internal homophobic Other. Indeed, Kulpa (2014) has convincingly demonstrated how the absence of the older EU member states in the resolution's critique of homophobic practices in Europe suggests that homophobia is more a problem of the East than of the West. This discursive move helped "to crystallise the core of the West/EUrope as [...] non-homophobic, hence respecting human rights values of tolerance, equality, liberty, and individuality" (Kulpa, 2014: 437). It is important to note, however, that due to the lack of internal enforcement mechanisms of fundamental rights within the EU, the practical and legal impact of these resolutions remains limited. Thus, rather than being a tool to discipline new member states, the resolutions are better conceived as being part of the EU's normative othering processes through which the EU's borders 
were redrawn to define both inferior Others within (a kind of second-tier member state) and universal norm-violating Others outside the EU. By doing so, the fundamental rights identity of the EU is being reinforced whilst at the same time promoting the idea that the EU has an exceptional record in protecting human and LGBT rights.

A second response to the identity crisis relates to the changes made to the enlargement's fundamental rights conditionality, which signal intensified normative othering processes. As an EU official explained, one of the lessons learned from the previous enlargements was that fundamental rights was insufficiently engaged within the pre-accession period. ${ }^{3}$ To overcome these issues, the enlargement strategy was altered to make the Copenhagen criteria a central feature of the enlargement process of the Western Balkan countries. This was achieved by introducing a chapter (Chapter 23) in the negotiation process that specifically deals with fundamental rights (Nozar, 2012). This move made fundamental rights not just a precondition for membership applications, but a central part of the pre-accession negotiations, reinforcing the notion that to be fully European one must adhere to EU values. Moreover, in order to overcome the fact that there is only a limited amount of hard acquis in many of the areas covered by chapter 23 , a benchmarking system was introduced. This benchmarking system in effect transformed the "clear distinction between 'inside' and 'outside' [...] into a more complex pattern of tendencies and proximities", and thus making the whole accession process about "shedding Eastness" (Kuus, 2007: 158-159) - a move which supports and complements the internal Othering process described above.

From 2010 onwards, the EU adopted several external relations policy documents - the 2010 toolkit and 2013 guidelines to promote and protect LGBT rights - that would emphasise LGBT rights more explicitly. These documents constitute what Ammaturo (2015) has called a 'Pink Agenda', i.e. a strategy that creates a divide between presumably LGBT-friendly EU and backward homophobic countries. Whilst the adoption of these policy documents and the increased reliance on LGBT rights as an Othering tool is in part a reflection of the globalisation of LGBT rights and political processes

\footnotetext{
3 Interview with an official from European Commission (DG Enlargement), 29 May 2013.
} 
within the EU itself (Ayoub and Paternotte, 2014), the increased focus on LGBT rights also has roots within the enlargement process. As a commission official explained, the prioritisation of LGBT rights was the result of homophobia in candidate countries. ${ }^{4}$ In other words, the resistance of candidate countries to the EU's promotion of LGBT rights led to the intensification of othering processes which would emphasise this identity marker. ${ }^{5}$

This becomes particularly evident in the European Commission's 2013 Enlargement strategy. Based on an observation that homophobia, discrimination and hate crimes targeting sexual and gender minorities are widespread in the Western Balkans and Turkey, this strategy document did not only identify LGBT issues as its key priority within its fundamental rights conditionality but also formulated demands that go beyond the hard acquis, including the need for 'zero-tolerance approach' to discrimination, inclusive 'education' and 'appropriate handling of Pride parades' (European Commission, 2013: 11). With this move, which notably occurred after the third consecutive ban of Belgrade Pride (Slootmaeckers, 2017a), LGBT rights became formally a part of the othering processes governing Enlargement, with pride parades in particular being used as a test to see how well candidate countries are shedding their 'otherness' (Slootmaeckers, 2017b).

In sum, the EU responded to the increased resistance to LGBT rights in some new member states and the subsequent identity crisis by intensifying its normative Othering processes with a particular emphasis on those elements that were initially resisted. As such, LGBT rights have become key within the EU enlargement process as a means to construct, maintain and police the EU's symbolic boundaries.

\section{The EU's LGBT-Friendly Identity as the Solution or Source of New Crisis?}

While I have examined how the EU responded to an identity crisis resulting from resistance within Self/Other relations by intensifying its use of normative Othering processes through an emphasis on

\footnotetext{
${ }^{4}$ Interview with an official from European Commission (DG Enlargement), 24 October 2013.

${ }^{5}$ The increased focus on LGBT rights in the enlargement process is also influenced by the resistance to the EU LGBT-friendly identity by more distant Others, such as Russia.
} 
LGBT rights, two important nuances are to be considered. Discussed in more details below, one must 1) note that the shift towards normative Othering processes has neither been complete nor linear, and 2) ask whether the responses to the experienced identity crisis have been successful in overcoming the crisis or instead deepened it.

Regarding the former, it should be emphasised that the increased reliance on normative Othering never replaced the geopolitical Othering processes. Rather, this shift was made possible by creating a pseudo-hierarchy of different Other positions within the enlargement process. With the prospect of enlarging toward a post-conflict region, the EU has initiated the Stabilisation and Association process (SAp) for the Western Balkans as a "preventive measure [...] to avoid ethnic conflicts like Kosovo to spread to the rest of the Balkan region" (Higashino, 2004: 359). As the Western Balkan countries had first to work towards the adoption and implementation of Stabilisation and Association Agreements before even considering submitting EU membership application, the EU had de facto created a pathway through which these countries could shift from one Other position to another. First, the SAp is based on temporal and geopolitical Othering processes that position the Western Balkan countries as contemporary reincarnations of the 'past Self' or a security threat to peace on the European continent (Slootmaeckers, 2017a). Yet, the SAp simultaneously constitutes a process through which the Western Balkans were to shed their incompatible Otherness by 'overcoming' their warring past. It is only after this is achieved that the Western Balkans countries could be considered potentially part of the Self and that the enlargement process, now emphasising normative Othering processes, could begin. In other words, the earlier-discussed responses to the internal identity crisis were only made possible by the 'temporal' organisation of Othering processes that are based on a pseudo-hierarchy of the different Other positions that constitute the EU identities.

This pseudo-hierarchy of Other positions and Othering processes can also be observed throughout the enlargement process of the Western Balkans itself. Although the emphasis was supposed to be on the fundamental rights and democracy promotion, these issues have taken a backseat whenever 
a perceived crisis, potentially threatening regional stability and security, emerged. Take for example, the Croatian experience. Due to Croatia's lack of cooperation with the International criminal Tribunal for the former Yugoslavia (i.e. dealing with the past and thus with roots in geopolitical and temporal Othering processes), Chapter 23 on fundamental rights was only opened toward the end of the accession process (Slootmaeckers and Touquet, 2016). Similarly, in the Serbian experience, whenever the 'frozen conflict' between Kosovo and Serbia reheated (including Kosovo's declaration of independence and the violence near the border in summer 2011), fundamental rights became of secondary importance within the enlargement process (Slootmaeckers, 2017a).

Noting this hierarchy, it is not surprising that the earlier-described intensification of the promotion of LGBT rights occurred only after a political deal was struck between Kosovo and Serbia. Indeed, EU officials explained in interviews that the prioritisation of LGBT rights within the accession process was the results of both developments within the EU as well as a continuous banning of the Pride parade in Serbia (an instance of resistance to the EU's identity). Crucially, they also commented that the timing of this shift was in part determined by the Serbia-Kosovo deal as it meant that the Commission felt safe enough to "assume that major negative events will not happen in the region in the future." ${ }^{6}$

The move towards the normative Othering processes within the enlargement process then is as much a continuation of previously existing approaches as it is a change. The difference between the enlargement toward the CEE and toward the Western Balkans can then mainly be found in the relation between normative and geopolitical Othering within negotiations. Whereas the emerging embrace of normative-based Othering within the enlargement to CEE was in tension with already present geopolitical Othering processes, the enlargement to the Western Balkans has resolved these tensions by a continued a more recognised hierarchicalisation of the different Other positions. Doing so allowed the EU increasingly to rely on the promotion of LGBT rights to construct its LGBTfriendliness as a particular articulation of its human rights identity.

\footnotetext{
${ }^{6}$ Interview with an official from European Commission (DG Enlargement), 06 March 2014.
} 
A second important nuance relates to the 'successfulness' of the responses to the experience of identity crisis. As explained above, when faced with resistance to its LGBT equality norms, the EU responded by re-enforcing a self-image of LGBT-friendliness in which the EU is envisioned as the place in the world where LGBT people are exceptionally well accepted and protected. Whilst the described processes have contributed to clearer external boundaries between the EU and its Others, it remains questionable whether the EU will be able to maintain its LGBT-friendliness in the long run. Indeed, though such identity is increasingly produced through the EU's external relations, recent developments within the EU have highlighted that the rebranding of the EU's fundamental values identity through a gender and sexuality lens has also created a sharpened crisis of identity within its boundaries.

Whereas in the early to mid-2000s there was a trend to dismiss anti-LGBT moves within the EU as actions by not-yet-fully-European actors (Kulpa, 2014), the widespread mobilisations against gender and sexual equality across the EU suggests that such processes of internal Othering are becoming increasingly strained. The various events across the EU (including mass demonstrations against same-sex marriage or the Istanbul convention, the spread of referenda on the constitutional definition of marriage, and the increased public speech by politicians seeking to limit LGBT visibility and limit sexual and reproductive health access) demonstrate that there is an "increased politicization of gender and sexuality, leading to new forms of opposition and changing alliances between oppositional actors" (Verloo and Paternotte, 2018: 1). And although these events are in part national phenomena, they are also embedded within a transnational movement in which citizens and politicians seek to defend national sovereignty and authenticity from the impact of globalising trends (Paternotte and Kuhar, 2017). As such, they should not just be considered through the frames of polarisation around sexuality and gender issues, but these movements are also part of a wider discussion on the meaning of Europe and "the collective destiny of Europe, understood as a standard-bearer of civilization" (Paternotte and Kuhar, 2017: 268). Such developments, in which the content of the fundamental values identity of the EU is being reconceptualised and renegotiated 
(Mos, 2018), combined with the current processes of European disintegration (e.g. Brexit), democratic backsliding (Krizsan and Roggeband, 2018), and the rise of right-wing politics (Kováts and Põim, 2015), raises doubts to how long the EU can continue to rely on LGBT rights to maintain its external symbolic boundaries.

In other words, the EU's responses to the internal resistance to the EU's LGBT-friendly identity that started in the 2000s did not consolidate the identity internally but, due to its external focus, rather contributed to intensifying the resistance against it. As these anti-gender politics are gaining traction across the EU, one can expect that normative othering processes which position homophobia outside the EU become untenable. Indeed, the very aim of these anti-gender movements is to redefine the EU's self into one that is based on so-called traditional values. If this trend continues and the contestation about what constitute European norms intensifies, this will in turn affect the EU's external relations as candidate countries will draw on the internal contestation to resist LGBT rights promotion. When this occurs, intensifying existing othering process might no longer work. Instead, it is more likely that the Othering processes within the enlargement process will shift to embrace new politics of inclusion and exclusion.

\section{Conclusion}

This article started from some critical questions about the EU's LGBT-friendly identity with the aim to get a better understanding of what processes underpin this identity. It fundamentally challenged the taken-for-grantedness of this identity by highlighting how the emergence of the EU selfconceptualisation as a beacon of LGBT friendliness has been a part of a wider agenda of defining and redefining the European polity's border. In order to examine the origin of such practice, this article has looked at the importance of identity crises and how they have shaped the ways in which the EU maintains its symbolic boundaries. This has been analysed within the specific context of the EU enlargement process, which is inherently embroiled with the question of the changing nature of the EU's boundaries. 
The analysis demonstrated how the othering processes underpinning the EU enlargement process changed in response to two sources of identity crisis: the fall of the Berlin Wall (as an external source of crisis) and the resistance to LGBT rights is some new member states (as an internal source). The former is important as saw the gradual introduction of normative othering processes within the EU identity process. The second crisis originated within the Self/Other relations and was driven by internal challenges to EU's human rights identity, particularly in relation to LGBT rights. In response to this identity crisis, the EU intensified its reliance on LGBT rights to create both internal and external others. This consolidation of normative Othering processes represents both a continuation of the processes established after the fall of the Berlin Wall, but also a change where the normative Othering process has become more specialised to not only demark the external boundaries but also abject undesired internal elements. The intensification of the LGBT-rights-based Othering processes has been made possible by the crystallisation of a pseudo-hierarchical organisation of the EU's different Other positions, where the protection of hard borders created by geopolitical othering takes priority. This hierarchy has been clearly demonstrated in the EU enlargement process, where fundamental rights issues have continuously been shifted to the background in the face of a security threats.

Such hierarchy of Other positions and Othering processes, however, has an important impact on the stability of the EU's LGBT-friendly identity. As normative Othering processes lead to more penetrable boundaries, the meaning of constructed human rights or LGBT-friendly identity is less fixed. Any internal contestation can lead to a new identity crisis. Indeed, with the increased anti-gender mobilisations, the content of the EU's LGBT-friendly identity has been fundamentally challenged. As these movements gain momentum in the EU, the Othering mechanism which excluded those who mobilise on traditional values as foreign to Europe are then becoming increasingly strained within the EU - and thus might lead to a demise of the LGBT-friendly identity.

How the current contestations by anti-gender mobilisations might impact the EU's LGBT-friendly identity remains nevertheless an empirical question to be explored over the coming period. An 
avenue for future research then is to look into whether or not new politics of inclusion and exclusion might emerge within the EU as a result of the current identity crisis and what form they take. Additionally, future research should further unpack the presented processes. Whilst this article highlighted the processes underpinning the EU identity formation, the question of how these processes are enacted and reproduced through the specific actions of different actors is yet to be examined in detail. Understanding who within European institutions has the power to define the European norms will enable us to only further unravel how the European LGBT-friendly identity emerged, but will also be key to understand how the contestation over these norms will impact the future processes of the EU identity formation and gauge the resilience of the current LGBT-friendly identity against existing norm contestations.

Finally, being aware of these politics of inclusion and exclusion, such as the ones highlighted in this article, are important as they have real consequences for the people whose rights are politicised. Although it was beyond the scope of this article, it is important to note the resistance to the EU's human rights and LGBT-friendly identity has real consequences for LGBT people. The promotion of LGBT rights as part of the EU's identity construction processes does not only make LGBT issues hypervisible abroad, which can lead to increased levels of violence, but it also obscures the existence of homophobia within, which may inhibit further efforts to improved lived experiences. As such, future research should also explore how the politics examined within this article affect LGBT people's lives.

\section{References}

Ammaturo, F.R. (2015). The "Pink Agenda": Questioning and Challenging European Homonationalist Sexual Citizenship. Sociology 49(6), 1151-1166.

Ayoub, P.M. (2016). When States Come Out: Europe's Sexual Minorities and the Politics of Visibility. 
Cambridge University Press.

Ayoub, P.M. and Paternotte, D. (Eds.) (2014). LGBT Activism and the Making of Europe: A Rainbow Europe? Palgrave Macmillan, Basingstoke.

Boin, A., 't Hart, P., Stern, E., and Sundelius, B. (2005). The Politics of Crisis Management: Public Leadership under Pressure. Cambridge Universiy Press, Cambridge.

Carstocea, S. (2006). Between acceptance and rejection. Decriminalizing homosecuality in Romania. In: Weyembergh, A., Carstocea, S. (Eds.), The Gays' and Lesbians' Rights in an Enlarged European Union. Institut d'Etudes Européennes, Brussels, pp. 207-222.

Crouch, C. and Marquand, D. (1992). Towards Greater Europe? A continent without an Iron Courtain. Davydova, D. (2012). Baltic Pride 2010: Articulating Sexual Difference and Heteronormative Nationalism in Contemporary Lithuania. Sextures 2(2), 32-46.

Delanty, G. (2006). Borders in a Changing Europe: Dynamics of Openness and Closure. Comparative European politics 4(2), 183-202.

Derrida, J. (1992). The Other Heading: Reflections on Today's Europe. Indiana University Press, Bloomington.

Diez, T. (2004). Europe's others and the return of geopolitics. Cambridge Review of International Affairs 17(2), 319-335.

Diez, T. (2005). Constructing the Self and Changing Others: Reconsidering 'Normative Power Europe'. Millennium - Journal of International Studies 33(3), 613-636.

Diez, T., Stetter, S., and Albert, M. (2006). The European Union and Border Conflicts: The Transformative Power of Integration. International Organization 60(3), 563-593.

El-Tayeb, F. (2011). European Others: Queering Ethnicity in Postnational Europe. Minnesota University PRess, Minnesota.

European Commission (2013). Enlargement Strategy and Main Challenges 2013-2014.

Fuchs, D. and Klingemann, H.-D. (2002). Eastward Enlargement of the European Union and the Identity of Europe. In: Mair, P., Zielonka, J. (Eds.), The Enlarged European Union: Diversity and 
Adaptation. Frank Cass, London, pp. 19-54.

Graff, A. (2006). We Are (Not All) Homophobes: A Report from Poland. Feminist Studies 32(2), 434449.

Harrison, S. (2003). Cultural Difference as Denied Resemblance: Reconsidering Nationalism and Ethnicity. Comparative Studies in Society and History 45(2), 343-361.

Higashino, A. (2004). For the Sake of "Peace and Security"?: The Role of Security in the European Union Enlargement Eastwards. Cooperation and Conflict 39(4), 347-368.

Jensen, S.Q. (2011). Othering, identity formation and agency. Qualitative Studies 2(2), 63-78.

Kochenov, D. (2008). EU Enlargement and the Failure of Conditionality: Pre-accession Conditionality in the Fields of Democracy and the Rule of Law. Kluwer Law International, Alphen aan den Rijn, The Netherlands.

Kollman, K. and Waites, M. (2009). The Global Politics of Lesbian, Gay, Bisexual and Transgender Human Rights: an Introduction. Contemporary Politics 15(1), 1-17.

Kovács, M. and Kabachnik, P. (2001). Shedding Light on the Quantitative Other: the EU's Discourse in the Commission Opinions of 1997. In: Böröcz, J., Kovács, M. (Eds.), Empire's New Clothes: Unveiling EU Enlargement. Central Europe Review, Telford, pp. 147-195.

Kováts, E. and Põim, M. (Eds.) (2015). Gender as symbolic glue. The position and role of conservative and far right parties in the anti-gender mobilizations in Europe. FEPS-Foundation for European Progressive Studies, Budapest.

Krizsan, A. and Roggeband, C. (2018). Towards a Conceptual Framework for Struggles over Democracy in Backsliding States: Gender Equality Policy in Central Eastern Europe. Politics and Governance 6(3), 90.

Kuhar, R. and Takács, J. (Eds.) (2007). Beyond the pink curtain: Everyday life of LGBT people in Eastern Europe. Peace Institute - institute for Contemporary Socal and Political Studies, Ljubljana.

Kulpa, R. (2014). Western leveraged pedagogy of Central and Eastern Europe: discourses of 
homophobia, tolerance, and nationhood. Gender, Place Culture A Journal of Feminist Geography 21(4), 431-448.

Kuus, M. (2007). Something old, something new: Eastness in European Union enlargement. Journal of International Relations and Development 10(2), 150-167.

Lister, R. (2004). Poverty. Polity Press, Cambridge.

Manners, I. (2002). Normative Power Europe: A Contradiction in Terms? Journal of Common Market Studies 40(2), 235-258.

Manners, I. and Whitman, R. (2003). The "difference engine": constructing and representing the international identity of the European Union." Journal of European Public Policy 10(3), 380404.

Mole, R. (2011). Nationality and sexuality: homophobic discourse and the 'national threat' in contemporary Latvia. Nations and Nationalism 17(3), 540-560.

Mos, M. (2014). Of Gay Rights and Christmas Ornaments: The Political History of Sexual Orientation Non-discrimination in the Treaty of Amsterdam. Journal of Common Market Studies 52(3), 632649.

Mos, M. (2018). The fight of the Religious Right in Europe: old whines in new bottles. European Journal of Politics and Gender 1(3), 325-343.

Neumann, I.B. (1998). European Identity, EU Expansion, and the Integration/Exclusion Nexus. Alternatives: Global, Local, Political 23(3), 397-416.

Nozar, W. (2012). The 100\% Union: The Rise of Chapters 23 and 24. In: Swoboda, H., Stetter, E., Wiersma, J.M. (Eds.), EU Enlargement Anno 2012: A Progressive Engagement. European Union, Brussels, pp. 87-96.

O'Dwyer, C. (2010). From Conditionality to Persuasion? Europeanization and the Rights of Sexual Minorities in Post-Accession Poland. Journal of European Integration 32(3), 229-247.

Paternotte, D. and Kuhar, R. (2017). The anti-gender movement in comparative perspective. In: Kuhar, R., Paternotte, D. (Eds.), Anti-Gender Campaigns in Europe: Mobilizing Against Equality. 
Rowman \& Littlefield International, London, pp. 253-276.

Puar, J.K. (2007). Terrorist Assemblages: Homonationalism in Queer Times. Duke University Press, London.

Putnina, A. (2007). Sexuality, Masculinity and Homophobia: The Latvian Case. In: Kuhar, R., Takács, J. (Eds.), Beyond the Pink Curtain: Everyday Life of LGBT People in Eastern Europe. Peace Institute - institute for Contemporary Socal and Political Studies, Ljubljana, pp. 313-326.

Qin, Y. (2018). A Relational Theory of World Politics. Cambridge University Press, Cambridge.

Rahman, M. (2014). Homosexualities, Muslim Cultures and Modernity. Palgrave, London.

Renkin, H.Z. (2009). Homophobia and queer belonging in Hungary. Focaal 2009(53), 20-37.

Rumelili, B. (2004). Constructing identity and relating to difference: understanding the EU's mode of differentiation. Review of International Studies 30(1), 27-47.

Sax, W.S. (1998). The Hall of Mirrors: Orientalism, Anthropology, and the Other. American Anthropologist 100(2), 292-301.

Slootmaeckers, K. (2017a). From 'Strategic Accession' to 'Tactical Europeanisation'?: The Promotion of and Resistance to LGBT Equality in Serbia's European Integration Process. PhD Thesis. Queen Mary University of London, UK.

Slootmaeckers, K. (2017b). The litmus test of pride: analysing the emergence of the Belgrade "Ghost" pride in the context of EU accession. East European Politics 33(4), 517-535.

Slootmaeckers, K. and Touquet, H. (2016). The co-evolution of EU's Eastern Enlargement and LGBT politics: An ever gayer Union? In: Slootmaeckers, K., Touquet, H., Vermeersch, P. (Eds.), The EU Enlargement and Gay Politics: The Impact of Eastern Enlargement on Rights, Activism and Prejudice. Palgrave, London, pp. 19-44.

Smismans, S. (2010). The European Union's Fundamental Rights Myth. Journal of Common Market Studies 48(1), 45-66.

Smith, K.E. (2001). The EU, human rights and relations with third countries: 'foreign policy' with an ethical dimension? In: Smith, K.E., Light, M. (Eds.), Ethics and Foreign Policy. Cambridge 
University Press, Cambridge, pp. 185-203.

Smith, K.E. (2005). The outsiders: the European neighbourhood policy. International Affairs 81(4), 757-773.

Verloo, M. and Paternotte, D. (2018). The Feminist Project under Threat in Europe. Politics and Governance 6(3), 1-5.

Wæver, O. (1996). European Security Identities. Journal of Common Market Studies 34(1), 103-132.

Wallace, W. (1992). From Twelve to Twenty-Four? The Challenges to the EC posed by the Revolutions in Eastern Europe. In: Crouch, C., Marquand, D. (Eds.), Towards Greater Europe? A Continent without an Iron Courtain. The Political Quarterly, Oxford, pp. 34-51.

Wendt, A. (1994). Collective Identity Formation and the International State. American Political Science Review 88(2), 384-396. 